\title{
Physiological and Mechanical Properties of Kiwifruit Tissue Associated with Texture Change during Cool Storage
}

\author{
F.R. Harker and I.C. Hallett \\ The Horticulture and Food Research Institute of New Zealand, Mount Albert Research Centre, Private \\ Bag 92 169, Auckland, New Zealand.
}

Additional index words. ripening, softening, fruit texture, Actinidia deliciosa, flesh firmness

\begin{abstract}
Kiwifruit [Actinidia deliciosa (A. Chev) C.F. Liang et A.R. Ferguson] flesh firmness can decline by as much as 94\% during fruit ripening. This phenomenon was investigated at the cellular level, with the aim of characterizing changes in the physiological condition and mechanical properties of cells. The tensile strength of kiwifruit outer pericarp tissue was measured, and low-temperature scanning electron microscopy was used to examine the mode of cell failure at fracture surfaces. The propensity with which cells ruptured was determined by incubating tissue discs in hypertonic and hypotonic solutions, and water potentials, osmotic potentials, turgor pressures, and tissue density were measured. An initial rapid reduction in flesh firmness-from 80 to $27 \mathrm{~N}$ during 6 weeks of storage at $0 \mathrm{C}$-was related to a reduction in the adhesion between neighboring cells. Following tensile tests, an examination of fracture surfaces indicated that cells from freshly harvested fruit had ruptured, exposing the cell interior. After 6 weeks of storage, neighboring cells separated from each other without breaking open. With 23 additional weeks of storage at $0 \mathrm{C}$, flesh firmness decreased from 27 to $5 \mathrm{~N}$. The final softening stage was associated with an increase in the proportion of cells that separated at the middle lamella and an increase in the plasticity of the cell wall.
\end{abstract}

Kiwifruit texture changes dramatically during fruit ripening, with flesh firmness declining from 60 to $90 \mathrm{~N}$ at harvest to 5 to 8 $\mathrm{N}$ when ripe (Beever and Hopkirk, 1990). The assessment of kiwifruit postharvest quality is largely based on flesh firmness measurements (Beever and Hopkirk, 1990), and sensory evaluation has demonstrated a significant relationship between flesh firmness and overall fruit acceptability (Stec et al., 1989).

The kiwifruit is made up of four tissue zones: the core, inner pericarp, outer pericarp, and skin. Each of these tissues differs in mineral (Ferguson, 1980) and cell wall composition (Redgwell et al., 1990) and cell characteristics (Hallett et al, 1992). The core is usually firmer than the outer pericarp (MacRae et al., 1989), and the inner pericarp, although there are no published firmness measurements, is expected to be softer than the outer pericarp.

Whole-fruit flesh firmness is typically measured as the maximum force required to push a probe (usually a penetrometer) into the outer pericarp. Thus, kiwifruit texture is assessed by measuring the mechanical properties of the outer pericarp tissue, which is composed of two populations of cells: giant cells ( 0.5 to $0.8 \mathrm{~mm}$ in diameter) dispersed in a matrix of smaller cells ( 0.1 to $0.2 \mathrm{~mm}$ in diameter) (Hallett et al., 1992). While changes in cell wall composition (Redgwell et al., 1992) and ultrastructure (Hallett et al., 1992) have been characterized during earlier studies of kiwifruit ripening, there is little information on the mechanical properties of kiwifruit cells. Such information is required to explain the role of changes in cell wall structure and composition in kiwifruit softening.

In a series of studies with apples and nectarines (Harker and Hallett, 1992; Harker and Sutherland, 1993) several techniquesincluding tensile tests, propensity for cell rupture and tissue density - were used to characterize the mechanical and cellular

Received for publication 7 Sept. 1993. Accepted for publication 3 Feb. 1994. This research was funded by the New Zealand Kiwifruit Marketing Board and the New Zealand Foundation for Research, Science and Technology. The cost of publishing this paper was defrayed in part by the payment of page charges. Under postal regulations, this paper therefore must be hereby marked advertisement solely to indicate this fact. properties of fruit tissue. In the present study, these methods were used investigate the changes in the mechanical properties of cells from the outer pericarp of kiwifruit during ripening.

\section{Materials and Methods}

Plant material. 'Hayward' kiwifruit weighing $\approx 110 \mathrm{~g}$ and with an average soluble solids concentration (SSC) of $8.7 \%$ were harvested from the HortResearch Orchard in Te Puke, New Zealand, on 13 May 1992. The fruit were placed in commercial trays with polyliners and stored at $0 \mathrm{C}$ for up to 29 weeks. Textural and cellular characteristics of the fruit were examined at harvest and at various times during cool storage. Fruit were assessed after being held for 1 day at $20 \mathrm{C}$ after cool storage.

Fruit texture. The firmness of 10 kiwifruit was measured by a hand-held penetrometer (7.9-mm-diameter probe) (Effegi, Alfonsine, Italy). Patches of skin were removed from opposite sides around the equator of each kiwifruit before flesh firmness was measured. The juice expressed during firmness measurements was collected directly onto a hand-held refractometer ( $0 \%$ to $20 \%)$ (Atago, Tokyo) to measure SSC. An additional 10 fruit were used to measure the tensile strength of kiwifruit outer pericarp tissue and skin (peel). Tangential 6-mm-thick blocks of outer pericarp tissue were cut from opposite sides of each kiwifruit, and a preshaped cutter was used to cut notches $4 \mathrm{~mm}$ apart radially into the block so that a $4 \times 6-\mathrm{mm}$ weakened waist occurred at the equator. Tshaped metal strips were fixed to both ends of the tissue block using a cyanoacrylate adhesive in a gel form (Selleys, Padstow, Australia) and small screws. The tissue was placed between the claws of a materials testing machine (model 4301; Instron, Canton, Mass.), and the claws were moved apart at a rate of $10 \mathrm{~mm} \cdot \mathrm{min}^{-1}$, stretching the tissue along its longitudinal axis. The force required for tissue failure was recorded, and samples of the fracture surface from four kiwifruit were viewed using low-temperature scanning electron microscopy (LTSEM), as described by Harker and Hallett (1992) and Harker and Sutherland (1993).

Skin. Two longitudinal samples of kiwifruit peel were obtained from the remaining quadrants of each kiwifruit using a hand-held 
peeler. The samples were prepared for tensile testing using the same methods described above, except that peel thickness (1 to 2 $\mathrm{mm}$ ) was measured using vernier calipers. To compare the tensile strength of peel and outer pericarp tissue, the force required for peel or tissue failure was divided by the cross-sectional area of the waist.

Air space. Six more kiwifruit were used to measure tissue density, water potential, juice osmotic potential, and juice specific gravity. Outer pericarp tissue density was determined using Archimedes principle (Harker and Sutherland, 1993) and converted to percentage air space using the following formula: percentage air space $=1-($ density/specific gravity of the juice $) \times 100$ (Hatfield and Knee, 1988).

Water relations. The specific gravity of the juice extracted from pericarp tissue using a garlic crusher was determined by collecting $200 \mu \mathrm{l}$ of juice into preweighed micropipette tips. The tips were then removed from the micropipette and reweighed to a precision of $\pm 0.00001 \mathrm{~g}$. Tissue water potential was measured using outer pericarp tissue discs ( $7 \mathrm{~mm}$ in diameter $\times 3 \mathrm{~mm}$ thick), which were blotted dry before being placed in the $0.25-\mathrm{ml}$ sample holder of a dewpoint psychrometer (Westcor, Logan, Utah). The discs were left for $5 \mathrm{~min}$ before the vapor pressure was measured. The osmotic potential of $100-\mu$ juice samples collected using a garlic crusher was also measured by dewpoint psychrometry. Osmotic potentials were subtracted from water potentials when calculating cell turgor.

Osmotic fragility of cells. The propensity with which cells burst when incubated in hypotonic solutions was examined using discs from at least six additional kiwifruit. Discs $(\approx 2 \mathrm{~g}, 9 \mathrm{~mm}$ in diameter, $4 \mathrm{~mm}$ thick) were rinsed in distilled water for $30 \mathrm{sec}$, blotted dry, and weighed with a precision of $\pm 0.001 \mathrm{~g}$ into triplicate $50-\mathrm{ml}$ flasks containing $20 \mathrm{ml}$ of 0 to $900 \mathrm{mOsmols}$ mannitol with $0.5 \mathrm{~mm} \mathrm{CaCl}_{2}$ and $0.5 \mathrm{~mm}$ mercaptobenzothiazole. The discs were removed from these solutions after $30 \mathrm{~min}$ and/or $4 \mathrm{~h}$, blotted dry, and reweighed. Changes in disc weight were plotted against mannitol concentration and the lowest concentration that did not cause cell rupture, estimated as described previously (Harker and Hallett, 1992; Harker and Sutherland, 1993). The difference between the osmotic potential of this mannitol solution and the osmotic potential of the cells (estimated from juice SSC) was used to indicate the osmotic fragility of the cells.

\section{Results}

The flesh softened in a similar pattern during 29 weeks of cool storage, whether measured using a penetrometer or tensile test (Fig. 1). There was a slightly greater loss of firmness using tensile (99\% decrease in texture) than penetrometer tests (94\% decrease in firmness).

The tensile strength of the skin was always far greater than the tensile strength of the outer pericarp tissue. Skin tensile strength decreased linearly during cool storage and, after 29 weeks, was only $27 \%$ of harvest value. The thickness of individual peel samples used in skin tensile tests varied between 0.8 and $2 \mathrm{~mm}$. However, there was no relationship between peel thickness and

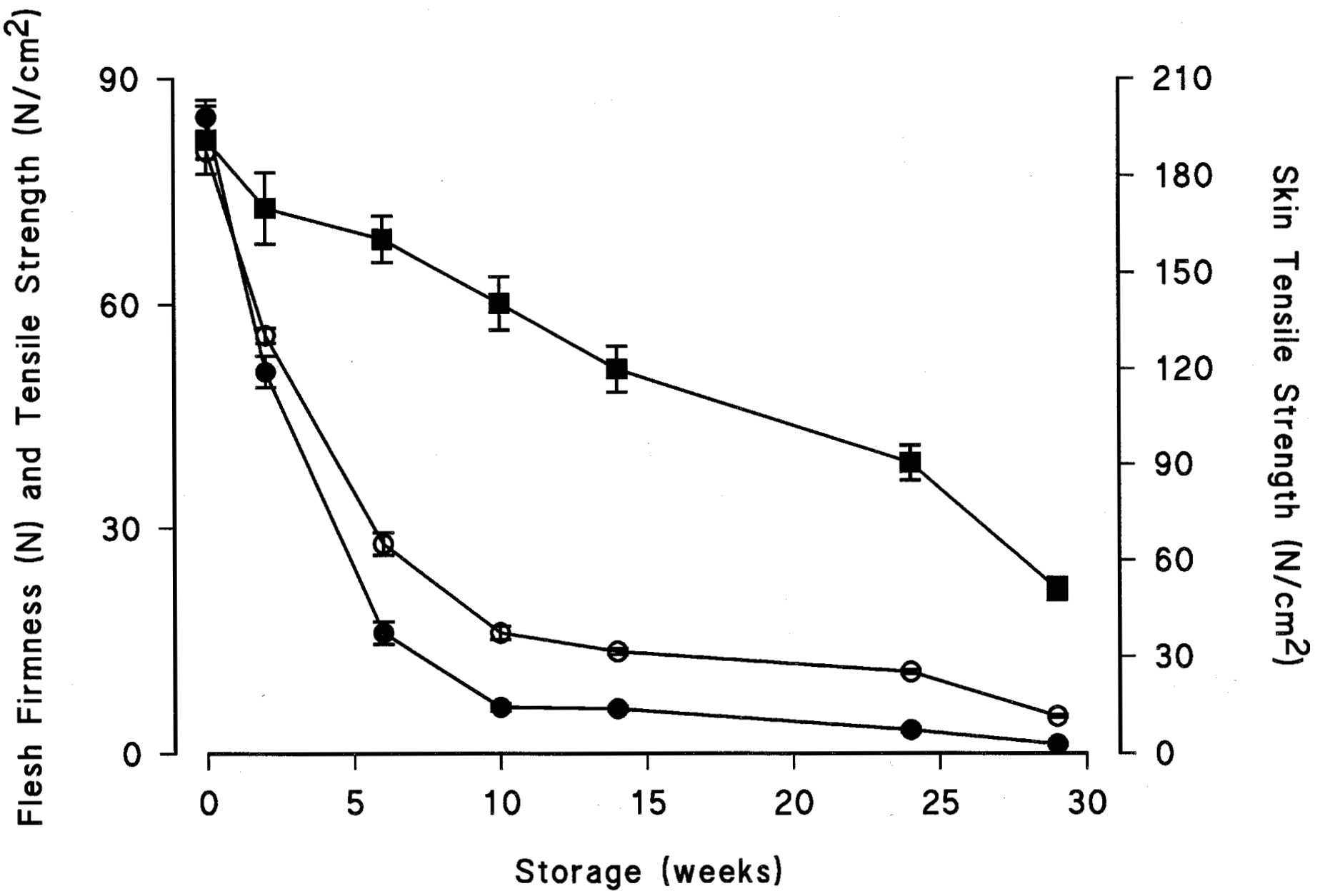

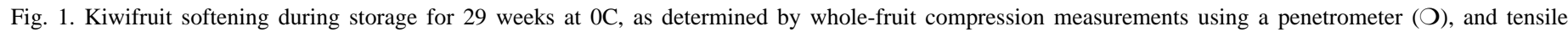
measurements of outer pericarp tissue (O) and skin $(\boldsymbol{\square})$. Points represent means \pm sE (vertical lines) for duplicate measurements on 10 fruit. 
skin tensile strength on any single assessment date, a result suggesting that the tensile strength of the peel samples was due to the outermost layers of the skin (usually $\approx 0.1 \mathrm{~mm}$ thick) and not the associated pericarp tissue.

An examination of fracture surfaces using LTSEM showed that, in freshly harvested fruit, virtually all giant and small cells had ruptured (Fig. $2 \mathrm{a}$ and b). The fracture was flat, and individual cells had snapped across their central region exposing their contents, including distinct starch grains. Following storage, the frequency of cells' remaining unbroken on the fracture surface increased. After as little as 2 weeks of storage, most of the giant cells in the tissue remained whole, and, by 6 weeks, all giant cells and many of the smaller cells detached from each other rather than breaking open (Fig. 2c). More smaller cells pulled apart from each other as storage continued and the fruit softened, although pockets of small cells continued to break (Fig. $2 \mathrm{~d}$ and e). Starch was no longer seen
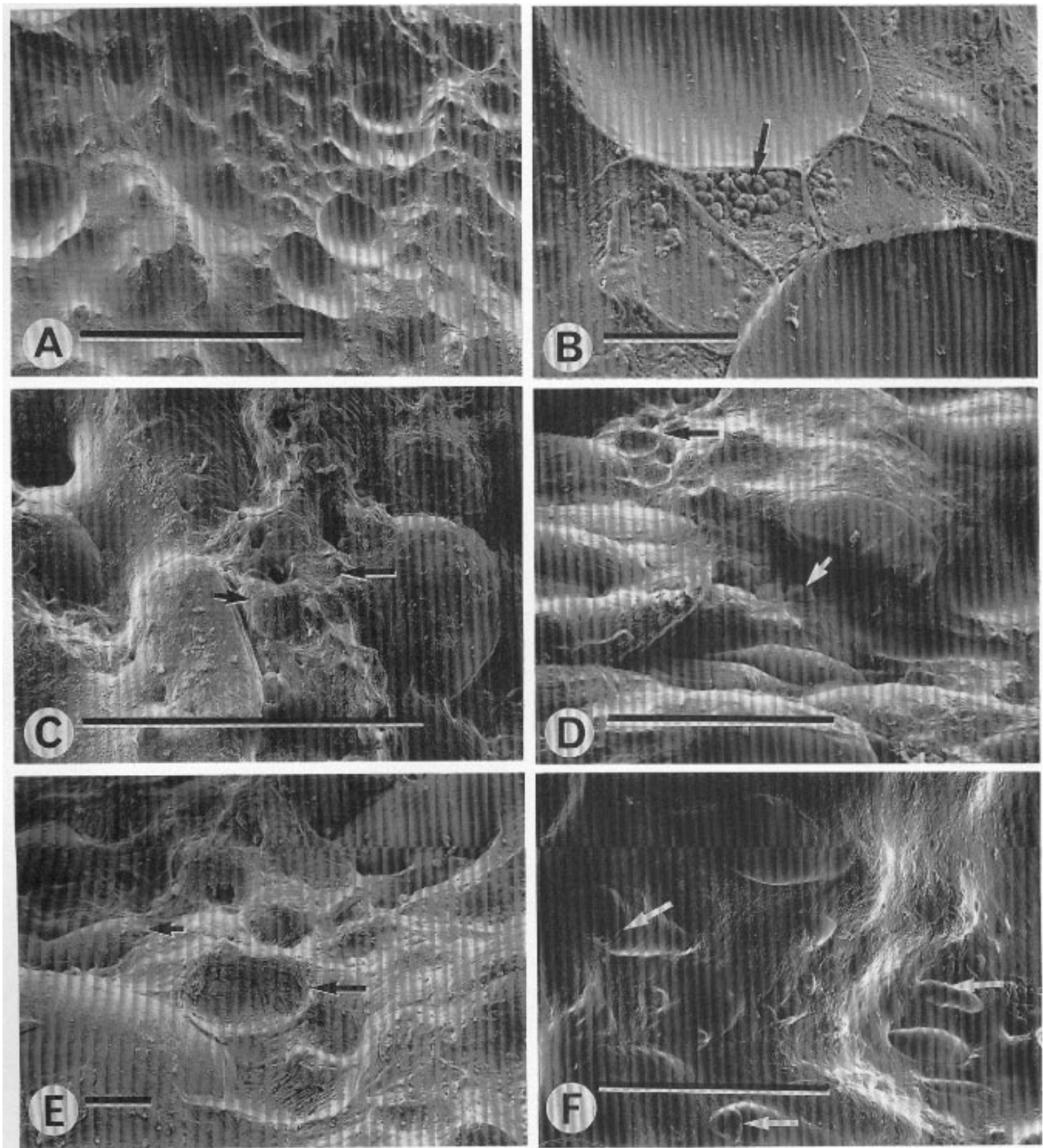

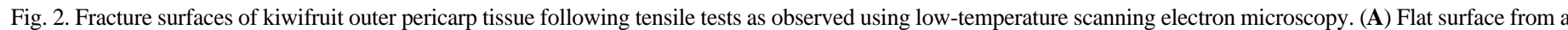

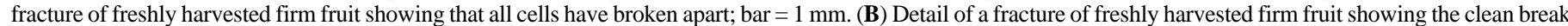

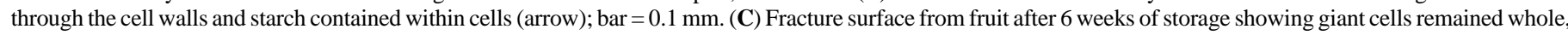

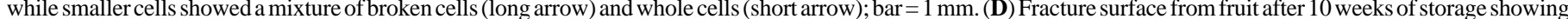

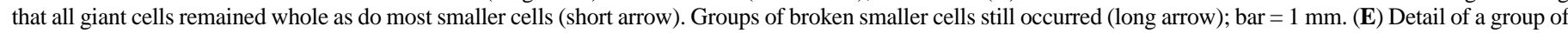

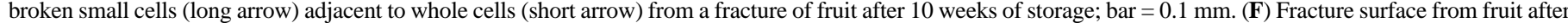
29 weeks of storage showing that cells protruded from extensive juice deposits. Cells were unbroken but frequently showed surface folding (arrows); bar $=1$ mm. 


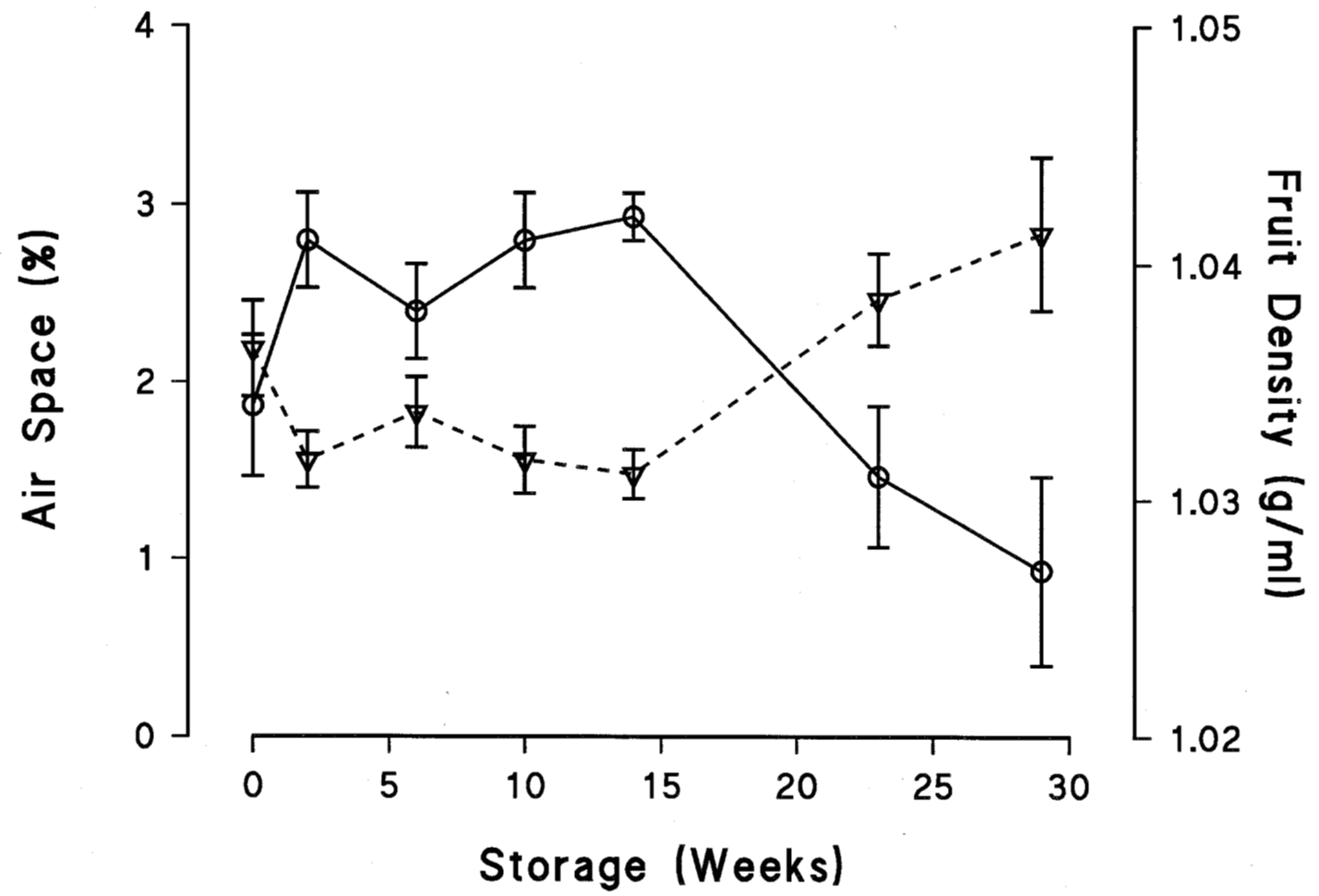

Fig. 3. Changes in tissue density and air space in kiwifruit outer pericarp tissue during cool storage. Points $(\bigcirc)$ represent mean density \pm SE (vertical lines) of six fruit and $(\nabla)$ mean airspace $\pm \mathrm{SE}$ (vertical lines) as calculated from density measurements (see text).

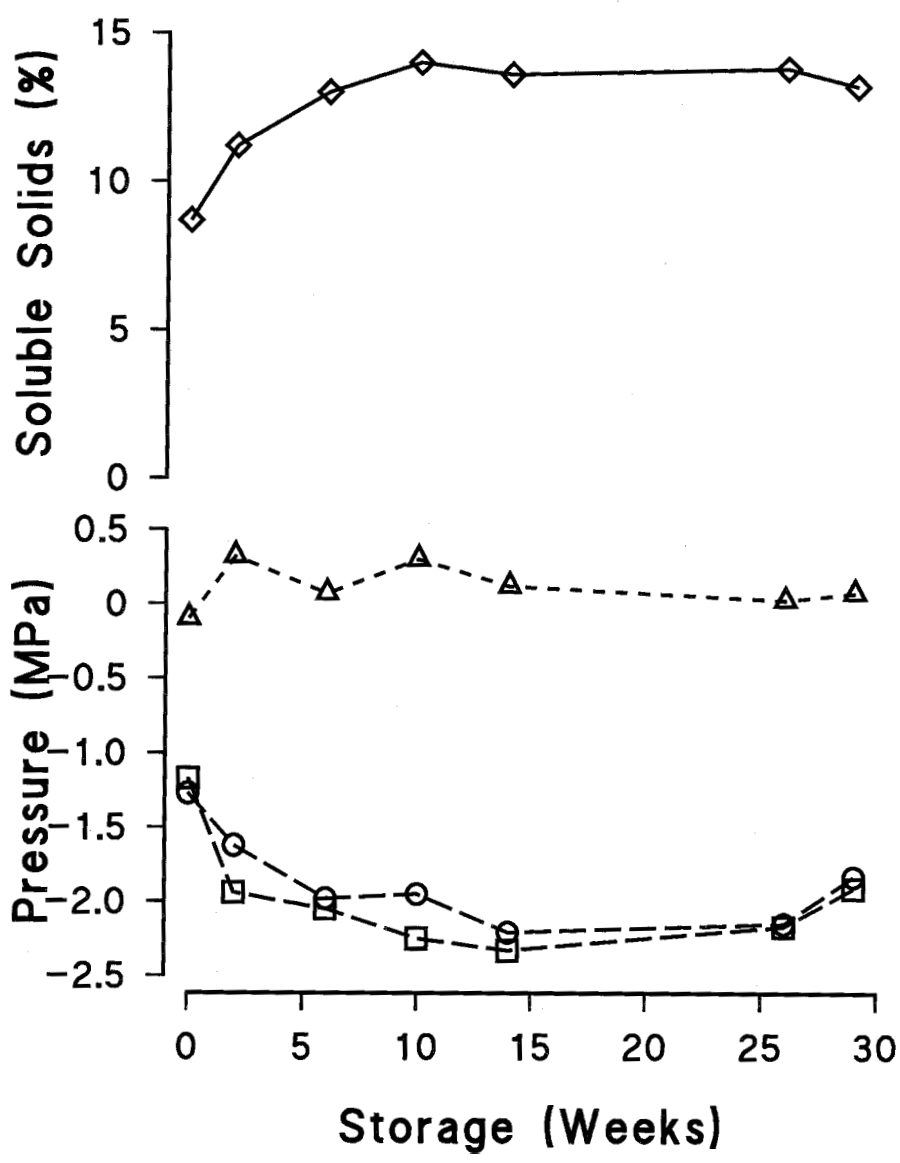

Fig. 4. Changes in soluble solids concentration $(\diamond)$, tissue water potential $(\bigcirc)$, juice osmotic potential( $(\square)$, and cell turgor pressure $(\Delta)$ inkiwifruit during cool storage. Points represent mean soluble solids concentration for samples of 10 fruit. Water relations values are means for samples of six fruit; SES were smaller than symbols. on the ruptured surface when fruit were stored for 10 weeks or longer. The surface of the fracture at these later storage stages was much more undulating than in freshly harvested fruit. At the final sampling time (week 29), no broken cells could be seen. The fracture surface was covered with extensive juice deposits, and the walls of many cells were folded or had collapsed (Fig. 2f).

Tissue density increased during the first 2 weeks of storage, remained relatively constant between 2 and 14 weeks storage, and then decreased from week 14 to 29 (Fig. 3). When these density measurements were converted to the proportion of tissue taken up by air spaces, using calculations described earlier (mean specific gravity of the juice $=1.057$ ), the proportion of air space in fruit varied between $1.4 \%$ and $2.8 \%$ (Fig. 3 ).

The osmotic potential $(\pi, \mathrm{MPa})$ of the juice decreased as SSC increased $\left(\pi=-0.19 \times \mathrm{SSC}+0.38, r^{2}=0.87\right)$. The tissue water potential and juice osmotic potentials decreased rapidly during the first 10 weeks of storage and more slowly during the following 19 weeks (Fig. 4). Calculated values for cell turgor varied between 0.07 and $0.32 \mathrm{MPa}$ on different assessment dates, although the mean turgor ( 2 to 29 weeks of storage) was $0.15 \mathrm{MPa}$. Calculations of turgor of cells in freshly harvested kiwifruit indicated a negative value, a result suggesting that methodological problems may have contributed to imprecise turgor values.

During incubation in mannitol solutions, disc weight changed as a result of influx and efflux of water, infiltration of extracellular regions, leakage of solutes, rupture of cells and the subsequent loss of cell contents, and perhaps other unknown causes (Harker and Sutherland, 1993). The point of maximum disc weight change decreased with increasing storage periods (Fig. 5a). However, within individual experiments, the pattern of increase and decrease in disc weight was critical in these experiments, since it was related to cell rupture and the flux of water. We assume that changes in weight not specifically driven by osmotic differences will occur to the same extent in all solutions. In each series of experiments, the 
percentage weight change became more positive as the concentration of mannitol decreased until a maximum value was reached (Fig. 5a). With further decreases in mannitol concentration, the percentage weight change declined (Fig. 5a). The maximum positive weight change was assumed to occur at the lowest concentration that did not cause cell rupture. The pattern of change in disc weight at this and higher concentrations of mannitol was associated with the influx and efflux of water, while cells ruptured and lost their contents when incubated in lower concentrations of mannitol. The concentration associated with cell rupture increased from 400 to $700 \mathrm{mOsmols}$ as fruit were stored from 0 to 10 weeks and decreased to 600 mOsmols at 29 weeks (Fig. 5a). These changes in concentrations required for cell rupture were associated with changes in the osmotic potential of the tissue, since starch hydrolysis continued during kiwifruit ripening. Thus, it was necessary to subtract the osmotic potential of the tissue from the osmotic potential of the solution to indication the tolerance to hypotonic stress (Fig. 5b). For these disc experiments, tissue osmotic potential was estimated from fruit SSC using the equation obtained from an earlier fruit sample.

Initial disc experiments involved incubation for $4 \mathrm{~h}$. However, at the 6-week assessment, the pattern of weight change was becoming indistinct. We subsequently examined the relationship between incubation period and the pattern of change in disc weight by measuring the weight of the same discs after $30 \mathrm{~min}$ and $4 \mathrm{~h}$. While the concentration that gave the maximum weight change was not altered, the pattern of increase and decrease in weight was more distinct after 30 min than $4 \mathrm{~h}$. Thus, experiments were continued using 30-min incubations. These differences in incubation periods complicate the assessment of changes in osmotic fragility in fruit stored for 0 and 2 weeks. However, experiments using discs from fruit stored for longer than 2 weeks were undertaken using consistent incubation periods.

\section{Discussion}

Kiwifruit firmness is usually measured after a patch of skin has been removed using a hand-held Effegi-type penetrometer that records the maximum force required to push a probe into the flesh. Generally, the force applied to the probe increases as the probe slowly penetrates further into the tissue until the force becomes so great that the tissue starts to disintegrate. Once tissue failure has

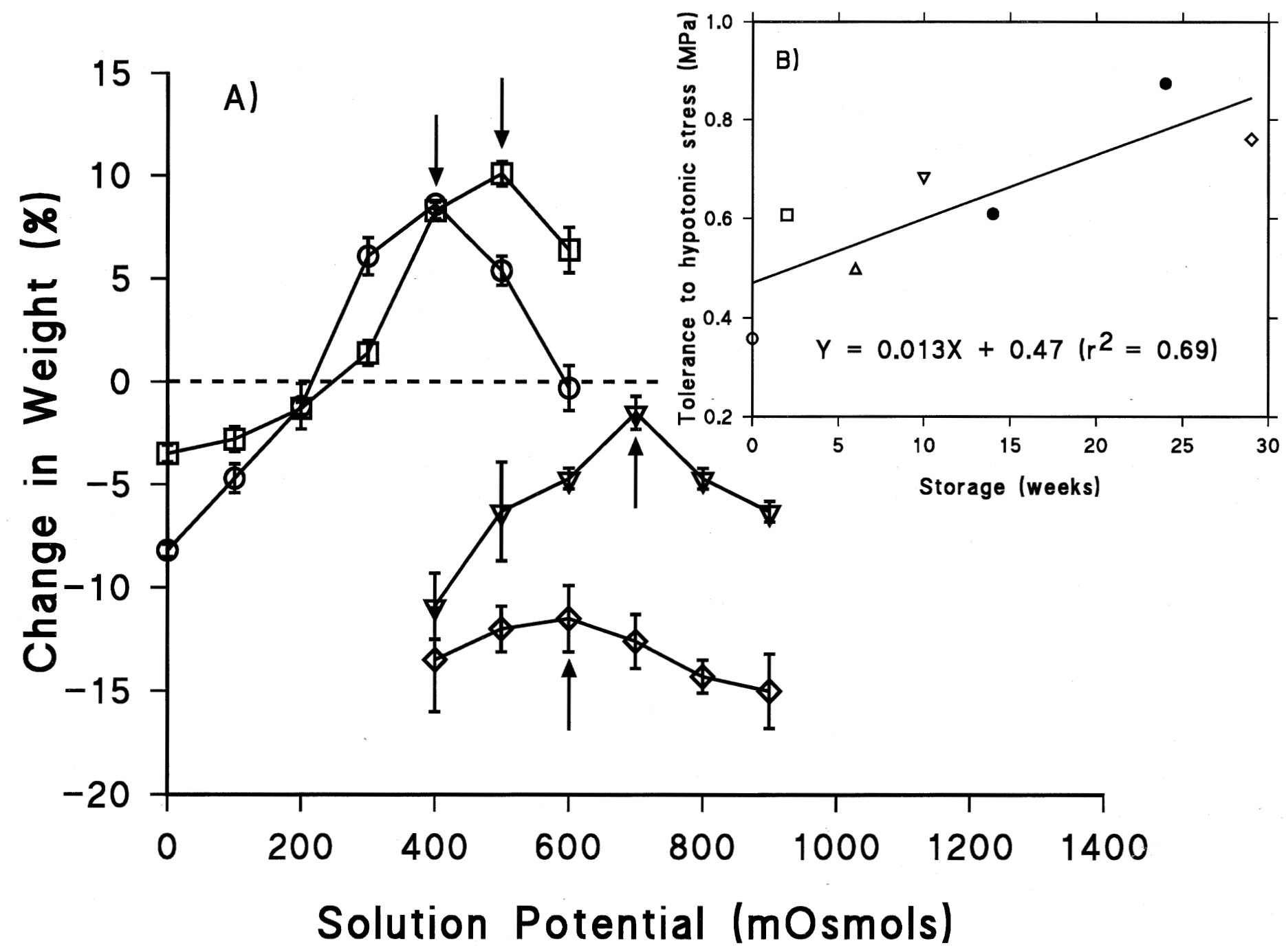

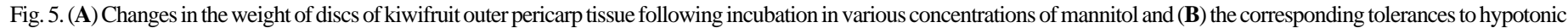

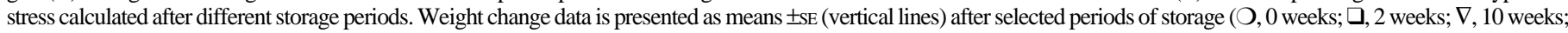

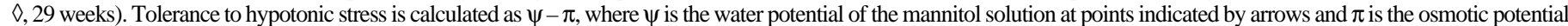
of juice. Discs were incubated in solutions for $4 \mathrm{~h}(\bigcirc$ and $\square), 30 \mathrm{~min}$ and $4 \mathrm{~h}(\Delta$ and $\nabla)$, or 30 min only $(\bigcirc$ and $\diamond)$. See text for more detailed explanation. 
started, the applied force does not usually increase above this maximum, no matter how deep the probe is pushed into the outer pericarp.

Kiwifruit skin may hold the fruit together, particularly at advanced ripening stages. Skin strength may influence the tactile assessment of firmness during commercial repacking and the nondestructive assessment of firmness using mechanical devices such as those discussed by Hopkirk et al. (1991). The tensile strength of kiwifruit skin is considerably higher than that of the outer pericarp tissue, and proportional differences in tensile strength of skin and pericarp tissue increased from 2 at harvest to 42 after 29 weeks of storage. This result suggests that the role of the skin in holding the fruit together becomes more important as kiwifruit soften.

Kiwifruit flesh softened rapidly during the first 6 weeks of cool storage (Fig. 1). Early softening was associated with considerable changes in the way that kiwifruit tissue fractured during tensile tests. At harvest, all cells exposed at the fracture surface had ruptured (Fig. $2 \mathrm{a}$ and b), a result suggesting that adhesion between neighboring cells was far greater than cell wall tensile strength. However, during the first 6 weeks of storage, adhesion between neighboring cells decreased so that most cells separated from each other without breaking (Fig. 2c). At the 6-week assessment, it was apparent that there were marked differences in adhesion between the two cell types. The giant cells were always undamaged at the fracture surface, whereas many of the small cells that surrounded the giant cells had broken (Fig. 2c). The proportion of the small cells that broke decreased as fruit softened further (Fig. $2 \mathrm{c}-\mathrm{f}$ ). The reason that the adhesive properties of giant and small cells differ may be related to the frequency of plasmodesmatal connections between cells. Regions of kiwifruit cell wall close to plasmodesmatal regions seem to be protected during ripening (Hallett et al., 1992), thus, differences in plasmodesmatal frequency may influence adhesion between cells. Further research is required to determine whether such differences in the frequency of plasmodesmata exist between giant and small kiwifruit cells. The different relationships between area of cell-to-cell contact, total cell surface area, and cell volume may also be important in determining the amount of stretching that giant and small cells can withstand.

Chemical analysis of cell walls has indicated that considerable solubilization of pectic polymers occurs during the early stages of kiwifruit ripening (Redgwell et al., 1992). Along with results from the present study, this result suggests that the early changes in kiwifruit texture are primarily related to degradation of the middle lamella and the resulting decreases in cell-to-cell adhesion.

The osmotic fragility of cells is another characteristic that may influence the textural characteristics of fruit tissues. Cells rupture as a result of osmotic stress when placed in water or extremely hypotonic solutions (Simon, 1977). The ability of cells to withstand elevated internal pressures associated with osmotic stress has been used to indicate the fragility of the cell wall and plasma membrane (Harker and Hallett, 1992; Harker and Sutherland, 1993). In the present study, cells from ripe kiwifruit were more tolerant to incubation in hypotonic mannitol solutions than cells from unripe kiwifruit (Fig. 5b). We suggest that the reason for this tolerance in cells from ripe fruit is partly related to the elasticity or plasticity of the cell wall and plasma membrane. When unripe cells were placed in hypotonic solutions, turgor pressure increased and the cells eventually burst. However, when ripe cells were placed in hypotonic solutions, osmotic uptake of water resulted in cell expansion rather than a build up in turgor pressure. Thus, cell expansion and solute leakage helped establish osmotic equilibrium between cells and incubation solutions before cells ruptured.
This explanation is supported by the observation of folds in the surface of cells from ripe kiwifruit following tensile tests (Fig. 2f), a result suggesting plastic deformation of the cell wall, resulting in folding when tension was released. Ultrastructural studies also indicate considerable cell wall deterioration and swelling (Hallett et al., 1992). These ultrastructural changes, observations of folds in cell walls (Fig. 2f), and increasing tolerance to osmotic stress (Fig 5b) indicate that the mechanical properties of the cell wall changed during storage. The cell wall seemed to become less brittle as the fruit ripened. However, this can not be verified until methods for directly measuring the mechanical properties of the cell wall become available.

As kiwifruit ripened, the point of maximum disc weight change decreased from $\approx 10 \%$ to $-12 \%$ in discs from kiwifruit stored for 2 and 29 weeks, respectively (Fig. 5a). Similar changes have also been observed during nectarine ripening (Harker and Sutherland, 1993) and indicate considerable differences in the physiological condition of cells from unripe and ripe tissue.

Our calculations indicated that the volume of air space increased mainly during the late stages of kiwifruit ripening (Fig. 3), a result confirming earlier results obtained using morphometric methods (Hallett et al., 1992). Such an increase in air space suggests that cell shape has been altered (Harker and Hallett, 1992; Vincent, 1989).

Fruit texture is affected by the internal turgor pressure of cells. Lin and Pitt (1986) incubated plugs of apple and potato tissue in a range of concentrations of mannitol and then tested the mechanical properties of the tissue under compressive loads. They found that the yield stress of tissue incubated in low concentrations of mannitol was low, since the cells had burst before the compressive load was applied. However, when plugs were incubated in isotonic and hypertonic solutions, tissue failure occurred by cell rupture and cell-to-cell debonding respectively. These results are explained by models that suggest that the force required for cell wall rupture is reduced when the cell wall is prestressed, as occurs in cells that retain their turgidity as a result of incubation in isotonic solutions (Pitt, 1982; Pitt and Chen, 1983). Thus, the change in mode of tissue failure observed in kiwifruit during the initial rapid softening phase (Fig. 2 a-c) could be explained partly by a decrease in cell turgor. Unfortunately, the method used to determine cell turgor in the present study was not sensitive enough to measure small changes in turgor. Water potential and osmotic potential of the tissue decreased as fruit ripened. This was expected, since starch hydrolysis and SSC increases occur during kiwifruit ripening (Beever and Hopkirk, 1990). However, calculations did not show any distinct pattern of change in cell turgor during kiwifruit ripening. Other studies with tomatoes using pressure probes (Shackel et al., 1991) and nectarines using psychrometric methods (Harker and Sutherland, 1993) have indicated that turgor declines during ripening.

In conclusion, the rapid loss of fruit firmness during early ripening stages was accompanied by reduced adhesion between cells and resulted in cells separating at the middle lamella rather than rupturing. Tissue softening during later ripening stages was associated with further reductions in cell-to-cell adhesion and increases in the elasticity or plasticity of the cell walls. These changes in the mechanical properties of cells were closely related to changes in the chemical composition of the cell wall determined in earlier studies. Giant cells were less likely to rupture than small cells when the tensile strength of the tissue was measured. This result suggests that the relative numbers of giant and small cells and the chemical composition of the cell walls will determine kiwifruit texture. 


\section{Literature Cited}

Beever, D.J. and G Hopkirk. 1990. Fruit development and fruit physiology, p. 97-126. In: I.J. Warrington and G.C. Weston (eds.). Kiwifruit: Science and management. N.Z. Soc. Hort. Sci., Auckland.

Ferguson, I.B. 1980. Movement of mineral nutrients into the developing fruit of the kiwifruit (Actinidia chinensis Planch.). N.Z. J. Agr. Res. 23:349-353.

Hallett, I.C., E.A. MacRae, and T.F. Wegryzyn. 1992. Changes in kiwifruit cell wall ultrastructure and cell packing during postharvest ripening. Intl. J. Plant Sci. 153:49-60.

Harker, F.R. and I.C. Hallett. 1992. Physiological changes associated with development of mealiness of apple fruit during cool storage. HortScience 27:1291-1294.

Harker, F.R. and P.W. Sutherland. 1993. Physiological changes associated with fruit ripening and development of mealy texture during storage of nectarines. Postharvest Biol. Technol. 2:269-277.

Hatfield, S.G.S. and M. Knee. 1988. Effects of water loss on apples in storage. Intl. J. Food Sci. Technol. 23:575-583.

Hopkirk, G., A. White, and B. Mills. 1991. Measuring fruit firmness without destroying the fruit. N.Z. Kiwifruit 87:14-15.

Lin, T.-T. and R.E. Pitt. 1986. Rheology of apple and potato tissue as affected by cell turgor pressure. J. Texture Studies 17:291-313.

MacRae, E.A., N. Lallu, A.N. Searle, and J.H. Bowen. 1989. Changes in the softening and composition of kiwifruit (Actinidia deliciosa) affected by maturity at harvest and postharvest treatments. J. Sci. Food Agr. 49:413-430.

Pitt, R.E. 1982. Models for the rheology and statistical strength of uniformly stressed vegetative tissue. Trans. Amer. Soc. Agr. Eng. 25:1776-1784.

Pitt, R.E. and H.L. Chen. 1983. Time-dependent aspects of the strength and rheology of vegetative tissue. Trans. Amer. Soc. Agr. Eng. 26:1275-1280.

Redgwell, R.J., L.D. Melton, and D.J. Brasch. 1990. Cell wall changes in kiwifruit following post-harvest ethylene treatment. Phytochemistry 29:399-407.

Redgwell, R.J., L.D. Melton, and D.J. Brasch. 1992. Cell wall dissolution in ripening kiwifruit (Actinidia deliciosa) solubilization of the pectic polymers. Plant Physiol. 98:71-81.

Shackel, K.A., C. Greve, J.M. Labavitch, and H. Ahmadi. 1991. Cell turgor changes associated with ripening in tomato pericarp tissue. Plant Physiol. 97:814-816.

Simon, E.W. 1977. Leakage from fruit cells in water. J. Expt. Bot. 28:1147-1152.

Stec, M.G.H., J.A. Hodgson, E.A. MacRae, and C.M. Triggs. 1989. Role of fruit firmness in the sensory evaluation of kiwifruit (Actinidia deliciosa cv Hayward). J. Sci. Food. Agr. 47:417-433.

Vincent, J.F.V. 1989. Relationship between density and stiffness of apple flesh. J. Sci. Food Agr. 47:443-462. 